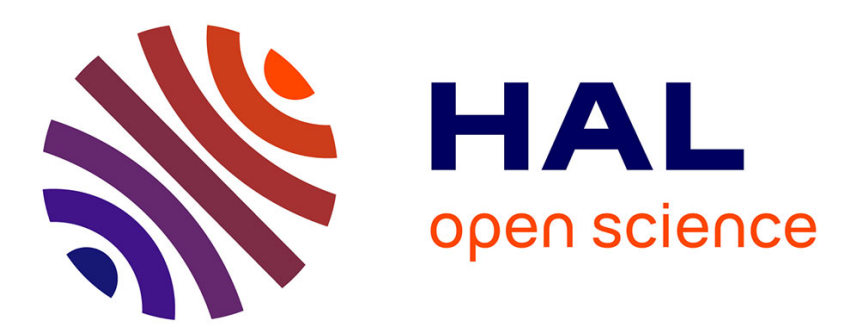

\title{
Microstructure characterization in electrodeposited Cu-coatings obtained at different bath temperatures
}

\author{
I. Handreg, P. Klimanek, H. Weidner
}

\section{To cite this version:}

I. Handreg, P. Klimanek, H. Weidner. Microstructure characterization in electrodeposited Cu-coatings obtained at different bath temperatures. Journal de Physique IV Proceedings, 1993, 03 (C7), pp.C7995-C7-998. 10.1051/jp4:19937154 . jpa-00251777

\section{HAL Id: jpa-00251777 https://hal.science/jpa-00251777}

Submitted on 1 Jan 1993

HAL is a multi-disciplinary open access archive for the deposit and dissemination of scientific research documents, whether they are published or not. The documents may come from teaching and research institutions in France or abroad, or from public or private research centers.
L'archive ouverte pluridisciplinaire HAL, est destinée au dépôt et à la diffusion de documents scientifiques de niveau recherche, publiés ou non, émanant des établissements d'enseignement et de recherche français ou étrangers, des laboratoires publics ou privés. 


\title{
Microstructure characterization in electrodeposited Cu-coatings obtained at different bath temperatures
}

\author{
I. HANDREG, P. KLIMANEK and H. WEIDNER
}

TU Mining Academy Freiberg, Department of Material Science, P.O. Box 49, 09599 Freiberg/Sa., Germany

\begin{abstract}
$\mathrm{X}$-ray profile and texture analysis, optical microscopy and microhardness measurement were used in order to study the dependence of the microstructure formation of electrodeposited copper coatings on the bath temperature. The coatings were obtained from an acid electrolyte without any additions within a temperature range from $-10^{\circ} \mathrm{C}$ up to $110^{\circ} \mathrm{C}$ on polycrystalline copper and amorphous carbon substrates.

The obtained temperature dependence of dislocation density is similar to that of the microhardness. Above room temperature the lattice perfection and the main grain size rapidly increase. At all temperatures deposition on carbon leads to a $\langle 110\rangle-f i b r e$ texture, but on copper substrates a texture change of the coatings from a $<110>-f i b r e$ to a more complicated, substrate-related epitaxial texture was observed.
\end{abstract}

\section{INTRODUCTION}

It is well known that microstructures and, consequently, properties of electrodeposites are strongly influenced by the special deposition conditions. As recently demonstrated for copper coatings the bath temperature is an important deposition parameter $[1,2,3]$. In the present paper some results concerning the correlations between the bath temperature and texture, microstructure, substructure (dislocation density) and the mechanical behavior (microhardness), respectively, will be represented.

\section{EXPERIMENTAL PROCEDURES}

The specimens of the present work were copper coatings of about $50 \mu \mathrm{m}$ thickness deposited on partially recrystallized (halfhard) copper and on amorphous carbon, respectively, from an acid electrolyte at temperatures between $-10^{\circ} \mathrm{C}$ and $110^{\circ} \mathrm{C}$.

The X-ray investigations were performed by means of a powder diffractometer HZG4 (Freiberger Präzisionsmechanik GmbH) using Cu-K $\alpha$ radiation and secondary beam monochromatization for background reduction. Substructure parameters were determined from the Fourier-coefficients of the physical line profile for the reflections $111,200,220,311$ and 222 after fitting of the experimental line shape and stokes correction by the procedures described in $[4,5,6]$.

For the texture analysis incomplete $X$-ray pole figures $\{111\},\{200\}$ and $\{220\}$ were measured by means of a texture accessory TZ6 mounted on the diffractometer HZG4. The evaluation was based on the interpretation of 
the three-dimensional orientation distribution function [7]. For imaging of the microstructure of the coatings optical microscopy of cross-section prepared samples were used. Microhardness measurements were carried out by a static tester (VICKERS intender - load 10 pond) of the type MP400 PC3 (Fa. Leco).

\section{EXPERIMENTAL RESULTS AND DISCUSSION}

1. Texture and microstructure

Fig.1 illustrates the influence of the bath temperature on the microstructure formation. The texture development in the copper coatings corresponds to that of the grain structure (Fig.1).

At low bath temperatures the so called field-orientated texture type is formed [8]. That means columnar grains grow parallel to the direction of the electric field lines with $a<110>-f i b r e$ texture. With increasing bath temperatures the microstructure becomes more and more inhomogeneous. In the case of the copper substrate simultaneously epitaxial growth is visible. Above $20^{\circ} \mathrm{C}$ the coatings are nearly completely formed by epitaxy in the basisorientated microstructure type [8]. In this connection the coating takes on the microstructure and texture of the copper substrate visible in the representation of the $\{220\}$-pole figure and the optical micrograph (Fig.2).

At amorphous carbon substrates the increased inhomogenity and coarsening of the grains is, how expected, not related to the substrat. The <110>texture splits up and seems to lead to a tendency of statistical orientation distribution.
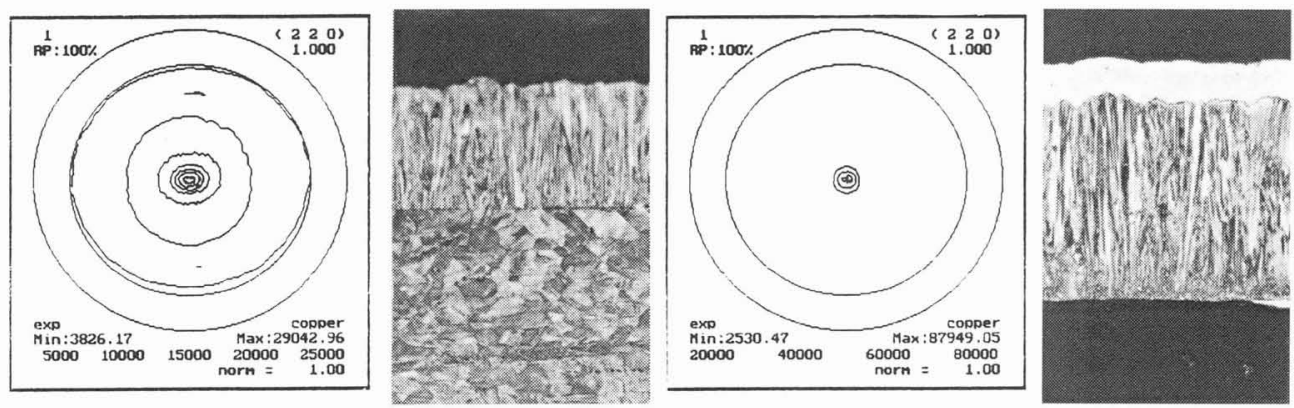

a) $-5^{\circ} \mathrm{C}$
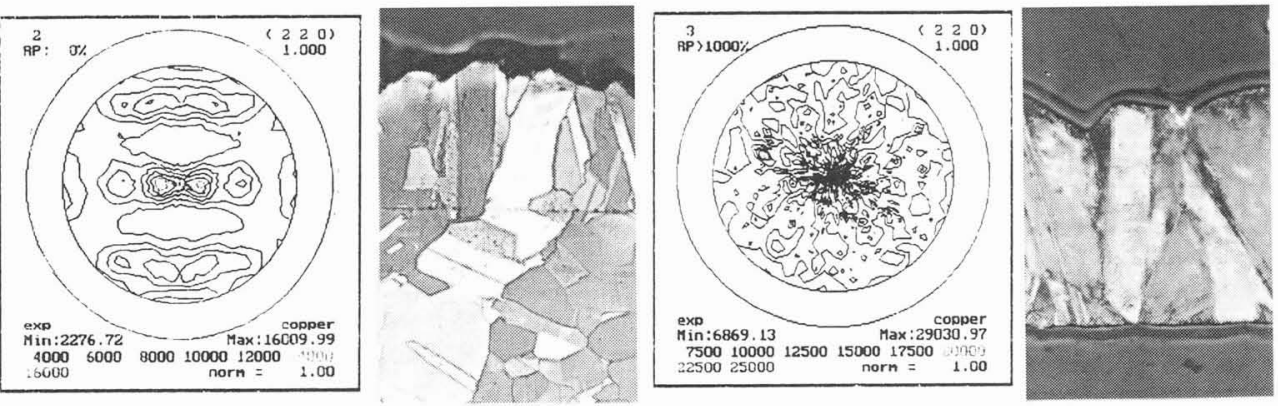

b) $90^{\circ} \mathrm{C}$

$\mathrm{Cu}-\mathrm{Cu}$

$\mathrm{Cu}-\mathrm{C}$

Fig. 1: (220)-pole figures and micrographs of the copper coatings 

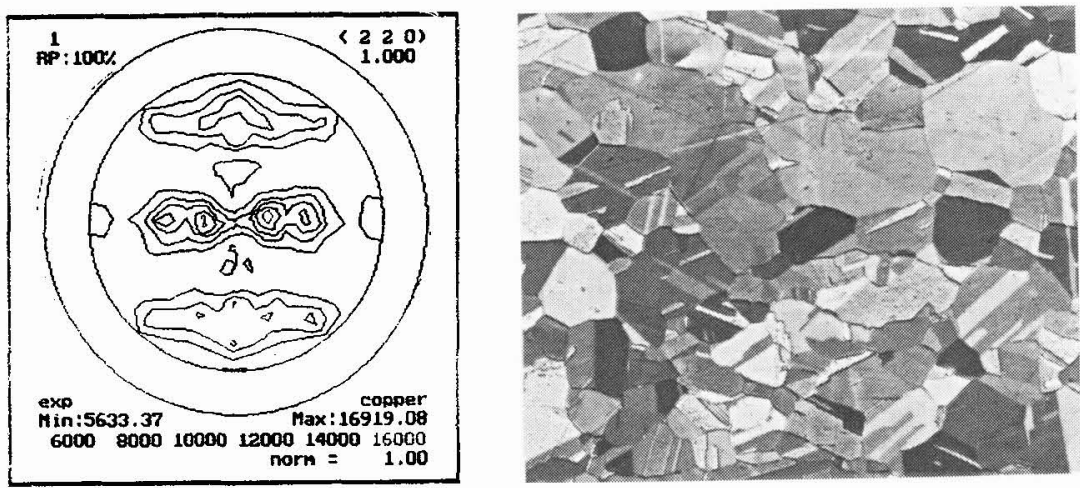

Fig. 2 : $\{220\}$-pole figure and micrograph of the copper substrate

\section{Substructure and microhardness}

With increasing deposition temperatures the microhardness of the copper coatings decreases from values of $150 \mathrm{HV}_{0.01}$ at low bath temperatures up to $80 \mathrm{HV}_{0.01}$ above $20^{\circ} \mathrm{C}$ (copper substrate) or $40^{\circ} \mathrm{C}$ (glasscarbon substrate), respectively (Fig. $3 a$ ).

microhardness HV 0.01

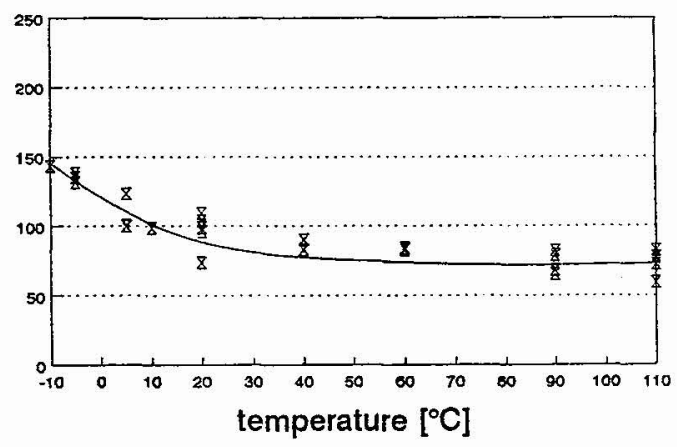

dislocation density $\left[1 E 10^{40} \mathrm{~cm}^{-2}\right]$ (reflex 220)

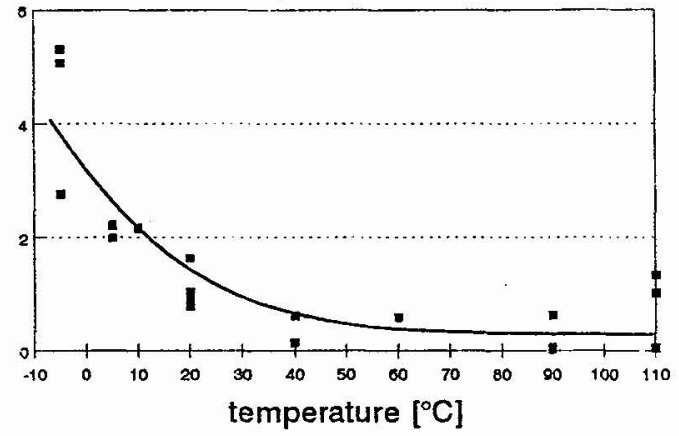

$\mathrm{Cu}-\mathrm{Cu}$ microhardness HV 0.01

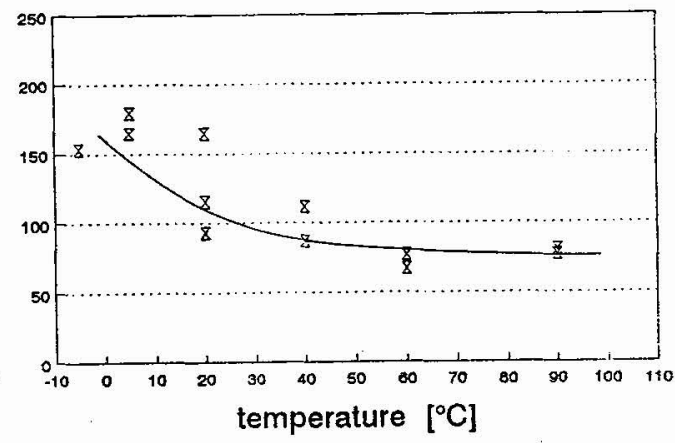

dislocation density $\left[1 \mathrm{E} 10^{\circ} \mathrm{cm}^{-2}\right]$ (reflex 220 )

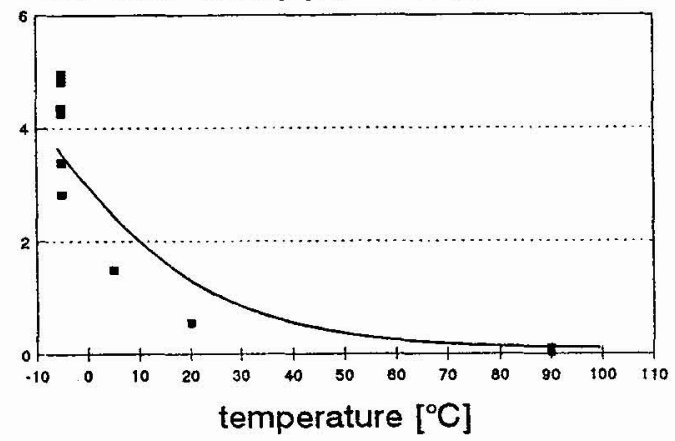

$\mathrm{Cu}-\mathrm{C}$

Fig. 3: Substructure analysis and microhardness 
Further increasing of the temperature results in a negligible difference between the microhardness of the coatings and the copper substrate. In correspondence a physical line broadening is observed only for bath temperatures below $20^{\circ} \mathrm{C}(\mathrm{Cu}-\mathrm{Cu})$ or $40^{\circ} \mathrm{C}(\mathrm{Cu}-\mathrm{C})$.

The microhardness and the physical line broadening of the copper coatings are of the same magnitude after deposition on copper as well as on carbon. Moreover, in coatings with a similar kind of microstructure no significant differences of dislocation densities were observed, and the estimated values correspond to the initial stage of plastic deformation of copper (Fig. 3b).

\section{CONCLUSIONS}

The formation of microstructure of the investigated copper coatings deposited from an acid electrolyte is strongly influenced by the bath temperature. At low deposition temperatures a fine grained, columnar structure with a $<110\rangle-f i b r e$ texture is formed, connected with dislocation densities corresponding to the initial stage of deformation and microhardness values about $200 \mathrm{HV}_{\mathrm{o.01}}$.

Increasing bath temperatures result in a coarsening of the grains and a texture transition due to epitaxial growth in the case of copper deposited on copper. Simultaneously the line broadening is drastically reduced, the grains become more perfectly and the micohardness decreases up to the magnitude of recrystallized bulk material.

The results indicate that the formation of the substructure is widely independent of the special substrate.

$\star * *$

The present paper was supported by the Arbeitsgemeinschaft Industrieller Forschungsvereinigungen $\mathrm{e} . \mathrm{V}$. (AIF) of the FRG.

\section{REFERENCES}

[1] SCHOLZ, R.R.; M.U. KITTEL; M. BAUMGAERTNER; Ch.J. RAUB: Galvanotechnik, 81(1990), pp. 4228

[2] HANDREG, I.; P. KLIMANEK, M. BAUMGAERTNER, Ch.J. RAUB: EPDIC 2, Enschede, July 30- August 1, 1992, Mat. Sci. Forum (1993)

[3] WEIDNER, H., P.KLIMANEK : EPDIC 2, Enschede, July 30- August 1, 1992, Mat. Sci. Forum (1993)

[4] STOKES, A.R. : Proc. Phys. Soc. (London) 61 (1948) 382

[5] DELHEZ, R.; T.H. de KETJSER, E.J. MTTTEMEIJER : Fresenius Z. Bys. hem. 312 (1982) 1

[6] KLIMANEK, P. : Freiberger Forschungsheft B265 (1988) 76-94

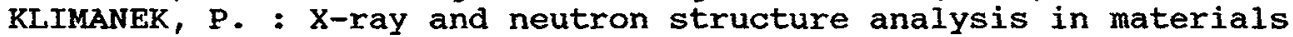
research (Ed. J. Hasek), Plenum Press, New York 1989, pp.125-137

KLIMANEK, P. : EPDIC 1 ,Munich, Mat. Sci. Forum 79-82 (1991) Pt. I, pp. $73-84$

[7] BUNGE, H.-J. : Quantitative Texture analysis in Materials science. Butterworth, London, 1984

[8] FISCHER, H. : Elektrolytische Abscheidung und Elektrokristallisation von Metallen, Springer Verlag, 1954 